\title{
Single-atom catalysis: Bridging the homo- and heterogeneous catalysis
}

\author{
Fang Chen a, Xunzhu Jiang a,b, Leilei Zhang a, Rui Lang a, Botao Qiao a,* \\ a State Key Laboratory of Catalysis, Dalian Institute of Chemical Physics, Chinese Academy of Sciences, Dalian 116023, Liaoning, China \\ b School of Chemistry, Dalian University of Technology, Dalian 116024, Liaoning, China
}

\section{A R T I C L E I N F O}

\section{Article history:}

Received 23 December 2017

Accepted 2 February 2018

Published 5 May 2018

\section{Keywords:}

Single-atom catalysis

Heterogenization of homogeneous

catalysts

Hydroformation

Hydrosilylation

Activation of $\mathrm{C}-\mathrm{H}$ bonds

\begin{abstract}
A B S T R A C T
Single-atom catalysis, the catalysis by single-atom catalysts (SACs), has attracted considerable attention in recent years as a new frontier in the heterogeneous catalysis field. SACs have the advantages of both homogeneous catalysts (isolated active sites) and heterogeneous catalysts (stable and easy to separate), and are thus predicted to be able to bridge the homo- and heterogeneous catalysis. This prediction was first experimentally demonstrated in 2016. In this mini-review, we summarize the few homogeneous catalysis progresses reported recently where SACs have exhibited promising application: a) $\mathrm{Rh} / \mathrm{ZnO}$ and $\mathrm{Rh} / \mathrm{CoO} \mathrm{SAC}$ have been used successfully in hydroformylation of olefin of which the activity are comparable to the homogeneous Wilkinson's catalyst; b) a $\mathrm{Pt} / \mathrm{Al}_{2} \mathrm{O}_{3} \mathrm{SAC}$ has shown excellent performance in hydrosilylation reaction; and c) $M-\mathrm{N}-\mathrm{C}$ SACs $(M=$ $\mathrm{Fe}$, Co etc.) have been applied in the activation of $\mathrm{C}-\mathrm{H}$ bonds. All of these examples suggest that fabrication of suitable SACs could provide a new avenue for the heterogenization of homogeneous catalysts. These pioneering works shed new light on the recognition of single-atom catalysis in bridging the homo- and heterogeneous catalysis.
\end{abstract}

(C) 2018, Dalian Institute of Chemical Physics, Chinese Academy of Sciences. Published by Elsevier B.V. All rights reserved.

\section{Introduction}

The concept of catalysis appeared less than 200 years ago. However, the phenomenon of catalysis has been known and utilized for thousands of years, although not so for its theory and characteristics. Catalysis has now played a central role in the modern chemical industry and in modern society. More than $85 \%$ of today's chemical products are produced by catalytic processes; and industrial catalysis contributes, both directly and indirectly through processes and products, to about $25 \%$ of the gross domestic product in developed countries [1].

Catalysis can be generally divided into two types according to the relationships between the phases of catalysts and reac- tants, i.e., homogeneous catalysis and heterogeneous catalysis, in addition to a rather special biocatalysis somewhere between the two [2]. In homogeneous catalysis, catalysts are in the same phase as the reactants, and often the products as well, which benefits the sufficient contact of the catalyst and reactant, thus resulting in high catalytic efficiency. Many homogeneous catalysts are composed of a (transition-) metal atom, or a cluster containing a few atoms, stabilized by appropriate ligands. The active sites can therefore be used effectively and are easy to identify. In addition, the catalyst properties as well as catalytic performance can be rationally tuned by changing the ligand. Accordingly, homogeneous catalysts generally possess not only high activity but also extremely high, and usually tunable, se-

\footnotetext{
* Corresponding author. Tel: +86-411-84379416; Fax: +86-411-84685940; E-mail: bqiao@dicp.ac.cn

This work was supported by National Natural Science Foundation of China (21606222, 21776270), and Postdoctoral Science Foundation (2017M621170, 2016M601350).

DOI: 10.1016/S1872-2067(18)63047-5 | http://www.sciencedirect.com/science/journal/18722067 | Chin. J. Catal., Vol. 39, No. 5, May 2018
} 
lectivity. However, the major issue of separating homogeneous catalysts from the raw materials and the products has severely limited their industrial application. Thus, in spite of the significant promise offered by homogeneous catalysts, few have been commercialized [3].

Heterogeneous catalysis, on the contrary, nominally covers all the cases in which catalysts and reactants are in different phases. However, in most cases, heterogeneous catalysis refers to a solid catalyst catalyzing a gas-gas or gas-liquid reaction. Although heterogeneous catalysts are usually less active and/or selective compared with homogeneous catalysts, they are quite stable and easy to separate from the reaction system. Therefore, most industrial catalysis is so far based on heterogeneous catalysis processes [4]. The comparison of the advantages and disadvantages of homo- and heterogeneous catalysts are listed in Table 1 [5]. To utilize the advantages of both homo- and heterogeneous catalysts, heterogenization of homogeneous catalysts has been attempted since the late 1960s, generally by attaching the homogeneous catalyst to an insoluble support via various physical or chemical interactions-so-called homogeneous catalyst heterogenization [6]. This process is very attractive and has been extensively studied. However, decades of study have proven that it is extremely difficult for various reasons [7]. Nevertheless, newly emergent single-atom catalysis may provide an alternative for the heterogenization of homogeneous catalysts and may bridge homoand heterogeneous catalysis.

The term "single-atom catalysis" was first proposed in 2011 in a seminal work by Prof Zhang Tao and coworkers [8]. This concept has been gradually accepted by the catalysis community in recent years and has become a new frontier in the catalysis field [9-15]. Single-atom catalysis means catalysis by a "single-atom catalyst" (SAC), which refers to the catalyst that contains only isolated single atoms dispersed on a support [16]. The most important structural feature of SACs is their isolated, individual atoms dispersed on the support, which not only maximizes the metal's atomic efficiency but also provides more uniform, well-defined active sites compared with common heterogeneous catalysts that consist of various kinds of active sites [17]. This renders SACs more active and selective than common heterogeneous nanocatalysts for numerous reactions and makes them behave like homogeneous catalysts in terms of both local structure and catalytic performance. The properties of SACs compared with both homo- and heterogeneous cata- lysts are also listed in Table 1. In short, SACs are heterogeneous catalysts and are thus quite stable and easy to separate; meanwhile, they possess isolated active sites similar to those of homogeneous catalysts, which provide them with the advantages of both homo- and heterogeneous catalysts. Thus, when the concept of "single-atom catalysis" was first proposed, researchers already foresaw and predicted that single-atom catalysis could provide a bridge between homo- and heterogeneous catalysis. However, it has not been demonstrated experimentally in the years following its introduction [9]. Only from 2016 has this prediction been experimentally verified gradually in a few progresses traditionally catalyzed by commercial homogeneous catalysis which will be highlighted in the following.

\section{Applications of SACs in traditional homogeneous catalysis progresses}

\subsection{Hydroformylation}

Hydroformylation of olefin is one of the most important homogeneously catalyzed industrial processes in industry [18]. It is a widespread strategy to produce aldehydes with olefins and syngas as feedstock, with more than 10 million tons produced globally on an annual basis. The desired aldehydes are value-added fine chemicals that are used as important organic intermediates for the synthesis of pharmaceuticals, agrochemicals, flavorings, and food additives and for the manufacture of plasticizers, coatings, adhesives, paints, and lubricant additives [19]. Nowadays, industrial hydroformylation is achieved mainly through three processes: the classic Co high-pressure process, the low-pressure process with phosphine-ligand-modified $\mathrm{Rh}$ complexes, and the aqueous biphasic hydroformylation process that is catalyzed by water-soluble Rh complexes [20]. The Rh-based heterogeneous catalysts for hydroformylation have been studied for more than 20 years but are still far from industrial application, primarily due to their much lower activity and selectivity compared with their homogeneous counterparts.

To verify our prediction that single-atom catalysis may bridge homo- and heterogeneous catalysis [9], we first investigated the application of SACs in the hydroformylation reaction [21]. After screening a number of catalyst formulas, we found that a $\mathrm{ZnO}$ nanowire-supported single-atom $\mathrm{Rh}$ heterogeneous

Table 1

Comparison of properties of homo- and heterogeneous catalysts.

\begin{tabular}{lccc}
\hline Property & Homogeneous catalysts & SACs & Heterogeneous catalysts \\
\hline Catalyst recovery & difficult and expensive & easy and cheap & easy and cheap \\
Thermal stability & poor & good & good \\
$\begin{array}{l}\text { Selectivity } \\
\text { Catalytic performance tunability }\end{array}$ & excellent/good & excellent/good/poor & good/poor \\
Active sites & pood & poor & poor \\
Uniformity of active sites & isolated atoms or clusters, often with ligand & isolated atoms, often with neighboring & multiple active sites \\
Metal electronic state & uniform & atoms from support & non-uniform \\
Atomic efficiency & depends on ligand, commonly positive & depends on support, commonly positive & commonly metallic \\
\hline
\end{tabular}

Some entries taken from Ref. [5] with permission from UNESCO-Encyclopedia of Life Support Systems (EOLSS). 
Table 2

Catalytic activity of Rh catalysts a.

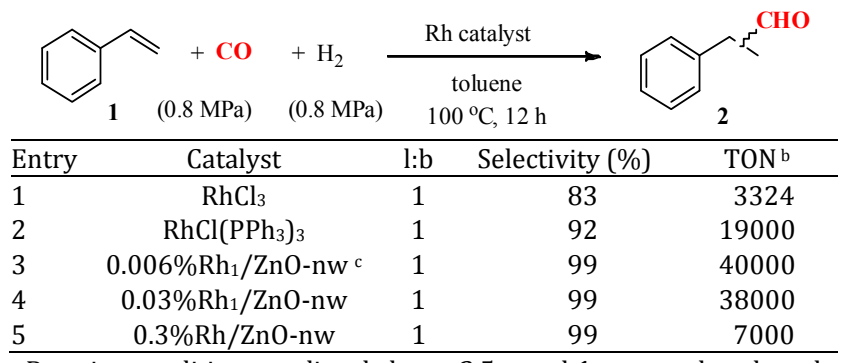

a Reaction conditions are listed above; $2.5 \mathrm{mmol} \mathbf{1}$ was used as the substrate; ${ }^{\mathrm{b}}$ TON $=$ turnover number; ${ }^{\mathrm{c}} \mathrm{nw}=$ nanowire.

catalyst exhibited comparable or even better catalytic performance compared with the classical Wilkinson's homogeneous catalyst $\left[\mathrm{RhCl}\left(\mathrm{PPh}_{3}\right)_{3}\right]$ in the hydroformylation of several olefin substrates under mild conditions (0.8 MPa CO, 0.8 MPa $\mathrm{H}_{2}, 100$ ${ }^{\circ} \mathrm{C}$ ); see Table 2 . In addition, it was also 1 or 2 orders of magnitude more active than most $\mathrm{Rh}$ heterogeneous catalysts reported previously. A combination of a series of characterizations, including aberration-corrected, high-angle annular dark-field scanning transmission electron microscopy (AC HAADF-STEM) and in situ diffuse reflectance infrared Fourier-transform spectroscopy of CO adsorption (CO-DRIFTS) experiments, confirmed that the isolated $\mathrm{Rh}$ atoms were dispersed on the ZnO support (Fig. 1A). In situ X-ray photoelectron spectroscopy (XPS) and X-ray adsorption near edge structure spectra (XANES) examination showed that the isolated Rh atoms were in a metallic or slightly negative state, suggesting that they occupied the 0 vacancies of $\mathrm{ZnO}$, and the electron transfer from $\mathrm{Zn}$ to $\mathrm{Rh}$ atoms occurred. This strong interaction between the metal (Rh) and the support ( $\mathrm{ZnO}$ ) led to a stable $\mathrm{Rh} / \mathrm{ZnO}$ $\mathrm{SAC}$, so that the catalyst showed excellent recyclability in the liquid-phase reaction. This work highlighted the superiority of SACs, i.e., they have isolated active sites similar to homogeneous catalysts and are quite stable like heterogeneous catalysts. Thus, for the first time, the prediction that SACs can bridge homo- and heterogeneous catalysis was demonstrated experimentally.

Almost concurrently, Zeng's group [22] developed a
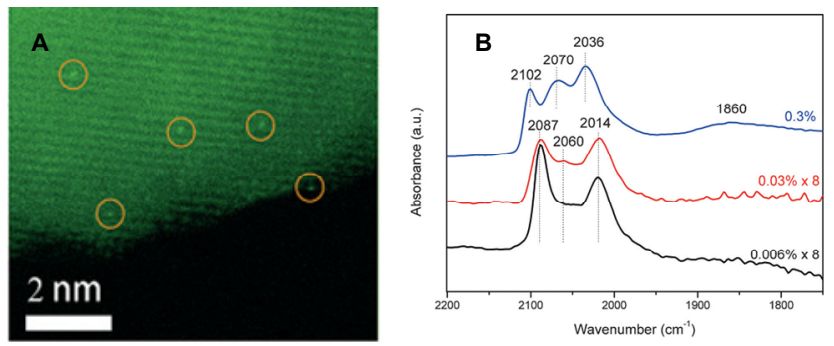

Fig. 1. HAADF-STEM image of $0.006-w t \% \mathrm{Rh}_{1} / \mathrm{ZnO}-\mathrm{nw} \mathrm{SAC}(\mathrm{A})$ and DRIFT spectra of $\mathrm{CO}$ adsorption on Rh/ZnO-nw catalysts with different Rh loadings (B). Reprinted with permission from Ref. [15]. Copyright 2016 Wiley-VCH Verlag GmbH \& Co. KGaA, Weinheim, Germany.

CoO-nanosheet-supported Rh SAC that was not only highly active but also regionally selective in the propene hydroformylation reaction. At optimal conditions, the selectivity for linear butyraldehyde could be as high as $94 \%$. To some extent, the regioselectivity is more important than the activity in regarding to the catalytic performance. Thus, this catalyst seems more valuable for practical applications than the Rh/ZnO SAC. For comparison, CoO-supported Rh nanocluster and nanoparticle (NP) catalysts were also tested. It was found that with increasing size, both the turnover frequency (TOF) and regioselectivity decreased: For 4.8 wt $\% \mathrm{Rh} / \mathrm{CoO}$ sample which mainly consisted of Rh NPs, the regioselectivity decreased to $50 \%$, i.e., the linear and branched products were the same, as suggested in Fig. 2A. HAADF-STEM demonstrated that singly dispersed Rh atoms occupied exactly the Co element positions (see Fig. 2B), and XPS showed that $\mathrm{Rh}$ existed as $\mathrm{Rh}^{3+}$ in the $\mathrm{Rh} / \mathrm{CoO} \mathrm{SAC}$, which was different from the Rh/ZnO SAC. Through the combination of in situ XPS, in situ DRIFT characterization, and density-functional-theory (DFT) calculations, the authors proposed that under the reaction conditions, the structure of $\mathrm{Rh}$ single atoms in $\mathrm{Rh} / \mathrm{CoO}$ was reconstructed, facilitating the adsorption and activation of the reactants; the reason for the high linear-product selectivity was the kinetic control. This work again demonstrated that a SAC can be a desired catalyst to bridge homo- and heterogeneous catalysis and suggested that selectivity may be controlled by modulating the single atom's coordination environment through supports instead of organic lig-
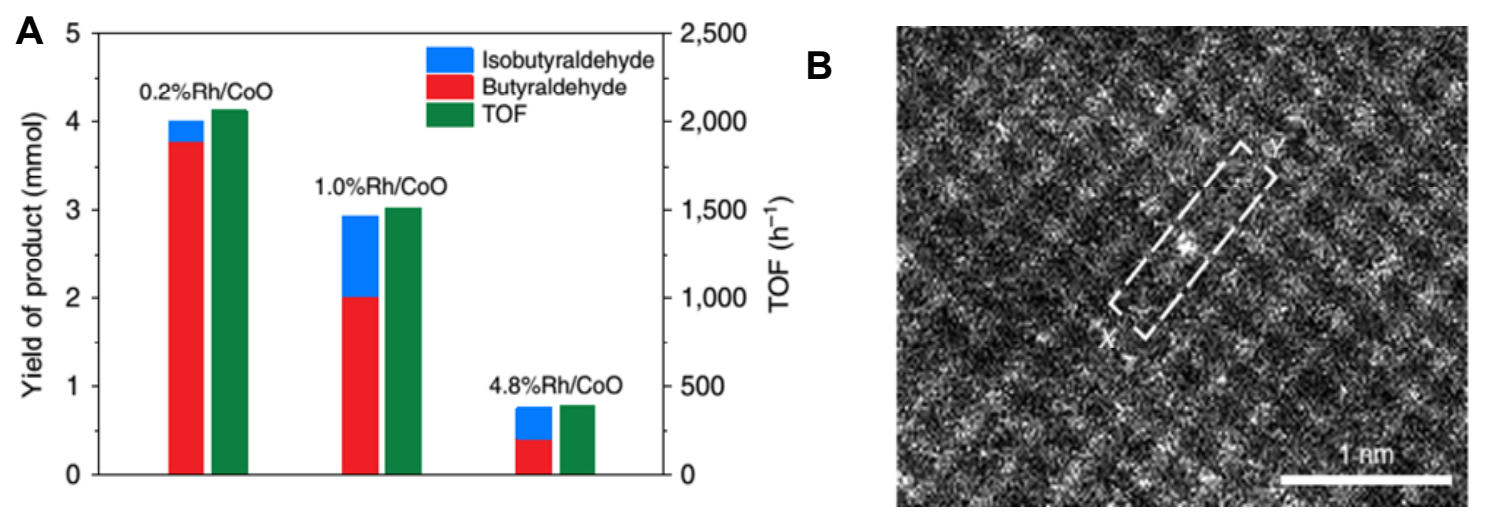

Fig. 2. TOFs and product yields of $\mathrm{Rh} / \mathrm{CoO}$ catalysts with different $\mathrm{Rh}$ loadings in the hydroformylation of propene at $100{ }^{\circ} \mathrm{C}$ after $2 \mathrm{~h}(\mathrm{~A})$ and HAADF-STEM of $0.2 \mathrm{wt} \% \mathrm{Rh}_{1} / \mathrm{CoO}$ SAC (B). Reprinted with permission from Ref. [16]. Copyright 2016 Springer Nature. 
ands.

\subsection{Hydrosilylation}

Hydrosilylation, adding the $\mathrm{Si}-\mathrm{H}$ bonds onto unsaturated bonds, is an important approach for the formation of organosilicon compounds that are widely applied in polymer chemistry, organic synthesis, and materials science [23]. To induce this reaction, ultraviolet-light irradiation, heat, or a catalyst, is needed. The catalytic method has commonly been chosen because of its high selectivity and mild reaction conditions. For decades, homogeneous platinum complexes, such as Speier's catalyst $\left(\mathrm{H}_{2} \mathrm{PtCl}_{6}\right)$ and Karstedt's catalyst, have played vital roles as catalysts in the industrial hydrosilylation reaction, and hydrosilylation has been one of the most important applications of Pt in homogeneous catalysis [24]. Other homogeneous transition-metal catalysts containing $\mathrm{Rh}, \mathrm{Pd}, \mathrm{Fe}, \mathrm{Co}$, or $\mathrm{Ni}$, and heterogeneous Pt-based catalysts, were continuously developed, but most showed less activity than the homogeneous Pt catalysts.

In 2016, Cui et al. [25] synthesized a $\mathrm{Pt} / \mathrm{Al}_{2} \mathrm{O}_{3} \mathrm{SAC}$ by depositing single $\mathrm{Pt}$ atoms on $\mathrm{Al}_{2} \mathrm{O}_{3}$ nanorods $\left(\mathrm{NR}-\mathrm{Al}_{2} \mathrm{O}_{3}\right)$ and studied its performance in hydrosilylation. Aberration corrected scanning transmission electron microscopy (AC-STEM) and extended X-ray absorption fine structure (EXAFS) examinations were employed to identify and demonstrate the SAC structure (Fig. 3A). This was the first time that hydrosilylation by a SAC was studied. Similar to the catalytic performance of a SAC in the hydroformylation reaction, the Pt SAC exhibited a comparable activity and selectivity to the classical homogeneous Karstedt's catalyst and much higher activity and recyclability than the Pt nanoparticle catalysts (see Fig. 3B). STEM, XANES, and EXAFS characterizations of the used $\mathrm{Pt} / \mathrm{NR}-\mathrm{Al}_{2} \mathrm{O}_{3} \mathrm{SAC}$ showed that compared to the unused catalyst, no significant differences were discovered, which proved the high stability of this catalyst in the hydrosilylation reaction. The substrate scope was also studied in detail. Many different tertiary silanes were first used to react with 1-octene. And then a variety of alkenes including linear or branched aliphatic olefins, oxygen-containing allylic compounds, olefins with a hetero-atom, such as $\mathrm{B}, \mathrm{Cl}, \mathrm{O}, \mathrm{N}, \mathrm{F}$, or $\mathrm{Si}$, and lignin-derived renewable olefins, were tested with di- ethoxymethylsilane as the silylation agent. In all cases, the TON reached $10^{5}$, and no side products were discovered. Then, different terminal olefins with other reducible groups, such as $\mathrm{C}=\mathrm{O}, \mathrm{C} \equiv \mathrm{N}$, and $\mathrm{C}=\mathrm{C}$ bonds (located at the intramolecular position), were used to test the chemoselectivity of the Pt/NR- $\mathrm{Al}_{2} \mathrm{O}_{3}$ $\mathrm{SAC}$. It was found that only the terminal $\mathrm{C}=\mathrm{C}$ bonds participated in the reaction, and other unsaturated bonds remained intact. Finally, some industrially applied silanes were studied, including 2,4,6,8-tetramethylcyclotetrasiloxane, polyhedral oligomeric silsesquioxanes, and polysilanes (Polymethylhydrosiloxane, PL6020). With Pt/NR- $\mathrm{Al}_{2} \mathrm{O}_{3} \mathrm{SAC}$ as a catalyst, low alkene isomerization and high levels of anti-Markovnikov addition products were obtained. In brief, in addition to its high activity and selectivity, the Pt/NR- $\mathrm{Al}_{2} \mathrm{O}_{3} \mathrm{SAC}$ displayed excellent recyclability and a broad substrate scope. This work further confirmed that the development of suitable SACs could be an effective means of achieving homogeneous catalyst heterogenization.

\subsection{Selective oxidation of $\mathrm{C}-\mathrm{H}$ bonds}

The selective oxy-functionalization of hydrocarbons has long been considered an important reaction for producing high-value-added carbonyl compounds, such as aldehydes, ketones, carboxylic acid, and esters [26]. However, owing to the high dissociation energy of $\mathrm{C}-\mathrm{H}$ bonds and the possible side reaction of over-oxidation, the currently developed catalysts for this reaction usually suffer from poor selectivity and/or harsh reaction conditions [27,28]. Recently, $M$-N-C-based $(M=$ $\mathrm{Fe}, \mathrm{Co}$, etc.) SACs were reported to demonstrate excellent catalytic performance comparable to Pt-group metals in oxygen reduction reactions (ORRs) and oxidative transformations (e.g., oxidation of alcohols); therefore, it is expected that $M$-N-C-based SACs might be used in the selective oxidation reactions of C-H bonds. On this basis, Liu et al. [29] successfully synthesized uniform Fe-N-C SACs via pyrolysis of a Fe(phen) $)_{x}$ (phen denotes 1,10-phenanthroline) complex supported on $\mathrm{MgO}$ followed by acid leaching. EXAFS and HAADF-STEM characterization results clearly showed that Fe existed exclusively as single atoms. This Fe-N-C SAC exhibited excellent activity and selectivity for the selective oxidation of $\mathrm{C}-\mathrm{H}$ bonds with a
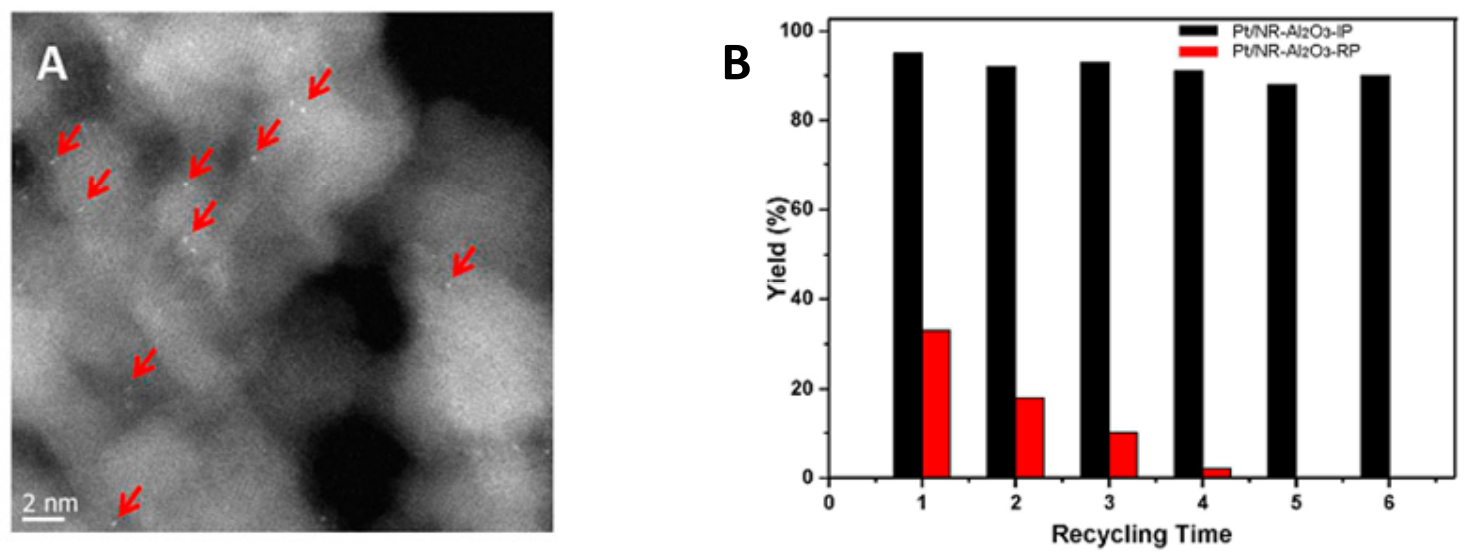

Fig. 3. HAADF-STEM images of Pt/NR- $\mathrm{Al}_{2} \mathrm{O}_{3}-\mathrm{IP}(\mathrm{A})$ and recyclability of Pt/NR- $\mathrm{Al}_{2} \mathrm{O}_{3}-\mathrm{IP}(\mathrm{SAC})$ and $\mathrm{Pt} / \mathrm{NR}-\mathrm{Al}_{2} \mathrm{O}_{3}-\mathrm{RP}$ (nanoparticle catalyst) in the hydrosilylation reaction (B). Reprinted with permission from Ref. [19]. Copyright 2017 American Chemical Society. 


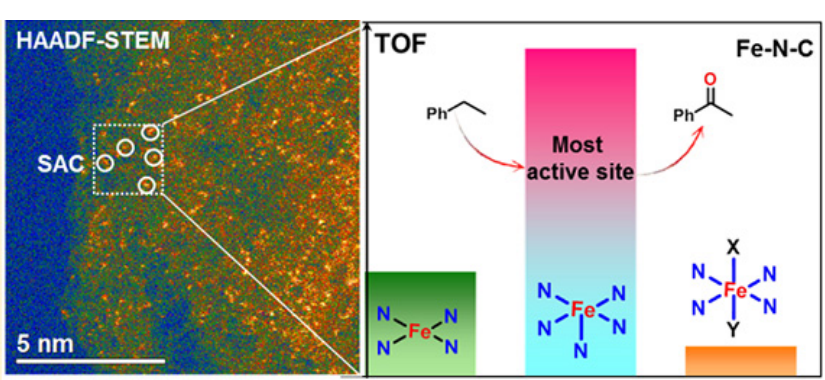

Fig. 4. HAADF-STEM image of Fe-N-C SAC and the TOF of different Fe- $\mathrm{N}_{x}$ structures on the Fe-N-C SAC for selective oxidation of ethylbenzene. Reprinted with permission from Ref. [20]. Copyright 2017 American Chemical Society.

broad scope of substrates at room temperature and represented one of the most active catalysts for the $\mathrm{C}-\mathrm{H}$ oxidation reaction reported in the literature. Furthermore, the catalyst could be reused at least five times without any decline in its catalytic activity. More importantly, by combining Mössbauer spectroscopy characterization and titration experiment results, the heterogeneity of Fe-N-C SAC was clearly demonstrated. That is, although all $\mathrm{Fe}$ species in the Fe-N-C catalysts existed as single atoms, they formed four different coordination structures with $\mathrm{N} / \mathrm{C}$ at different pyrolysis temperatures. Among them, the medium-spin FeN 5 species, although only accounting for $17.9 \%$ of all Fe species, exhibited a TOF value at least 1 order of magnitude higher than that of other Fe species (such as Fe- $\mathrm{N}_{4}-\mathrm{C}$ and Fe- $\mathrm{N}_{6}-\mathrm{C}$ ) and was considered to be responsible for the catalyst's overall performance. Interestingly, the structure of the $\mathrm{FeN}_{5}$ species was similar to the active center of the hemoglobin molecule, where the central Fe was coordinated by four $\mathrm{N}$ atoms in a square plane, with the fifth $\mathrm{N}$ atom in the imidazole ring of a histidine residue in the axial direction. Therefore, the Fe-N-C SACs can be regarded as enzyme mimics in organic transformations, demonstrating the potential of SACs in bridging homoand heterogeneous catalysis.

In addition to Fe-N-C SACs, Co-N-C SACs [30] with a structure of $\mathrm{CoN}_{4} \mathrm{C}_{8}-2 \mathrm{O}_{2}$, in which the central Co atom is coordinated with four $\mathrm{N}$ atoms in graphitic layers and two $\mathrm{O}$ atoms in the axial direction perpendicular to the $\mathrm{Co}-\mathrm{N}_{4}$ plane, were also synthesized and showed excellent catalytic performance for the hydrogenative coupling reactions of nitroarenes to obtain azo compounds under mild reaction conditions.

\section{Summary}

The examples above have demonstrated that SACs, possessing the advantages of both heterogeneous and homogeneous catalysts, can indeed open a new route for the heterogenization of homogeneous catalysts and can thus play a role in bridging homo- and heterogeneous catalysis. We believe that many more examples that illustrate the application of SACs in homogeneous catalysis processes will appear in the near future. We also believe that the application of SACs in traditional homogeneous catalysis processes may open a new direction for the application of SACs and hope that the practical application of SACs can be realized soon. We further hope that this mini-review will enhance the understanding of single-atom catalysis in bridging homo- and heterogeneous catalysis.

\section{References}

[1] G. Ertl, H. Knözinger, F. Schüth, J. Weitkamp, Handbook of Heterogeneous Catalysis, 2nd ed., Wiley-VCH Verlag GmbH\& Co. KGaA, Weinheim, 2008.

[2] G. Rothenberg, Catalysis: Concepts and Green Applications, Wiley-VCH, Weinheim, 2008.

[3] S. Bhaduri, D. Mukesh, Homogeneous Catalysis: Mechanisms and Industrial Applications, John Wiley \& Sons, Inc, 2014.

[4] H. Knözinger, K. Kochloefl, Heterogeneous Catalysis and Solid Catalysts, in: Ullmann's Encyclopedia of Industrial Chemistry, Wiley-VCH Verlag GmbH \& Co. KGaA, 2000.

[5] E. Farnetti, R. D. Monte, J. Kašpar, Homogeneous and Heterogeneous Catalysis, in: I. Bertiniaytexasphl (Ed.) Inorganic and Bio-Inorganic Chemistry, 50-87.

[6] C. Kemball, D. A. Dowden, M. S. Scurrell, Heterogenized Homogeneous Catalysts in: Catalysis, 1978, 215-242.

[7] P. Barbaro, F. Liguori, Heterogenized Homogeneous Catalysts for Fine Chemicals Production, in: B. James, P. W. N. M. v. Leeuwen (Eds.) Catalysis by Metal Complexes, Springer, 2010.

[8] B. T. Qiao, A. Q. Wang, X. F. Yang, L. F. Allard, Z. Jiang, Y. T. Cui, J. Y. Liu, J. Li, T. Zhang, Nat. Chem., 2011, 3, 634-641.

[9] X. F. Yang, A. Q. Wang, B. T. Qiao, J. Li, J. Y. Liu, T. Zhang, Acc. Chem.

\section{Graphical Abstract}

Chin. J. Catal., 2018, 39: 893-898 doi: 10.1016/S1872-2067(18)63047-5

\section{Single-atom catalysis: Bridging the homo- and heterogeneous catalysis}

Fang Chen, Xunzhu Jiang, Leilei Zhang, Rui Lang, Botao Qiao* Dalian Institute of Chemical Physics, Chinese Academy of Sciences; Dalian University of Technology

Several examples demonstrating that single-atom catalysts, with the advantages of both homogeneous catalysts (isolated active sites) and heterogeneous catalysts (stable and easy to separate), can bridge homo- and heterogeneous catalysis.

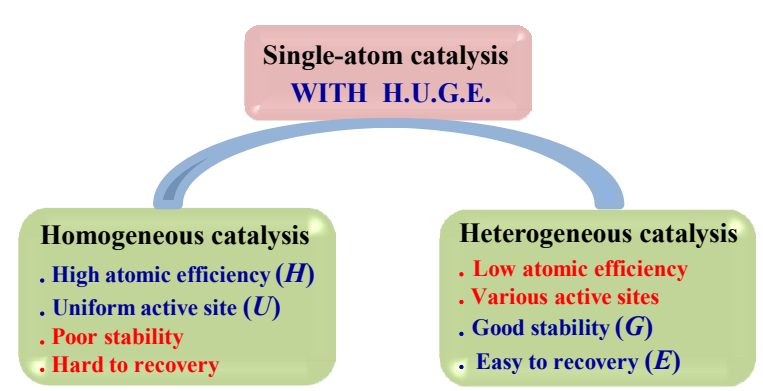


Res., 2013, 46, 1740-1748.

[10] M. Flytzani-Stephanopoulos, B. C. Gates, Annual Rev. Chem. Biomol. Eng., 2012, 3, 545-574.

[11] B. Han, R. Lang, B. T. Qiao, A. Q. Wang, T. Zhang, Chin. J. Catal., 2017, 38, 1498-1507.

[12] L. Q. Wang, L. Huang, F. Liang, S. M. Liu, Y. H. Wang, H. J. Zhang, Chin. J. Catal., 2017, 38, 1528-1539.

[13] Y. Wang, W. H. Zhang, D. H. Deng, X. H. Bao, Chin. J. Catal., 2017, 38, $1443-1453$.

[14] H. R. Zhou, X. F. Yang, A. Q. Wang, S. Miao, X. Y. Liu, X. L. Pan, Y. Su, L. Li, Y. Tan, T. Zhang, Chin. J. Catal., 2016, 37, 692-699.

[15] B. T. Qiao, J. X. Liang, A. Q. Wang, J. Y. Liu, T. Zhang, Chin. J. Catal, 2016, 37, 1580-1586.

[16] J. Y. Liu, ACS Catal., 2017, 7, 34-59.

[17] J. Li, J. Liu, T. Zhang, Chin. J. Catal., 2017, 38, 1431.

[18] R. Franke, D. Selent, A. Börner, Chem. Rev., 2012, 112, 5675-5732.

[19] Hydroformylation for Organic Synthesis, in: A. M. Maurizio Taddei (Ed.) Topics in Current Chemistry, Springer, Berlin, 2013.

[20] Fundamental Research in Homogeneous Catalysis, M. Graiani, M. Giongo (Ed.) Gordon and Breach Science, 1984.

[21] R. Lang, T. B. Li, D. Matsumura, S. Miao, Y. J. Ren, Y. T. Cui, Y. Tan, B. T. Qiao, L. Li, A. Q. Wang, X. D. Wang, T. Zhang, Angew. Chem. Int. Ed., 2016, 55, 16054-16058.
[22] L. B. Wang, W. B. Zhang, S. P. Wang, Z. H. Gao, Z. H. Luo, X. Wang, R. Zeng, A. W. Li, H. L. Li, M. L. Wang, X. S. Zheng, J. F. Zhu, W. H. Zhang, C. Ma, R. Si, J. Zeng, Nat. Commun., 2016, 7, 14036.

[23] Hydrosilylation A Comprehensive Review on Recent Advances, in: B. Marciniec (Ed.) Advances In Silicon Science, Springer, Dordrecht. 2009.

[24] H. Renner, E. Drost, Hans Martin Lüschow, P. Tews, P. Panster, M. Diehl, J. Lang, T. Kreuzer, A. Knödler, K. A. Starz, K. Dermann, J. Rothaut, R. Drieselmann, C. Peter, R. Schiele, Platinum Group Metals and Compounds, in: Ullmann's Encyclopedia of Industrial Chemistry, Wiley-VCH Verlag GmbH \& Co. KGaA, 2002.

[25] X. J. Cui, K. Junge, X. C. Dai, C. Kreyenschulte, M. M. Pohl, S. Wohlrab, F. Shi, A. Bruckner, M. Beller, ACS Cent. Sci., 2017, 3, 580-585.

[26] Y. Zhou, J. L. Long, Y. W. Li, Chin. J. Catal., 2016, 37, 955-962.

[27] L. H. Ren, L. Y. Wang, Y. Lü, G. S. Li, S. Gao, Chin. J. Catal,, 2016, 37, 1216-1221.

[28] N. Huo, H. Ma, X. H. Wang, T. L. Wang, G. Wang, T. Wang, L. L. Hou, J. Gao, J. Xu, Chin. J. Catal., 2017, 38, 1148-1154.

[29] W. G. Liu, L. L. Zhang, X. Liu, X. Y. Liu, X. F. Yang, S. Miao, W. T. Wang, A. Q. Wang, T. Zhang, J. Am. Chem. Soc., 2017, 139, 10790-10798.

[30] W. G. Liu, L. L. Zhang, W. S. Yan, X. Y. Liu, X. F. Yang, S. Miao, W. T. Wang, A. Q. Wang, T. Zhang, Chem. Sci., 2016, 7, 5758-5764.

\title{
单原子催化: 沟通均相催化与多相催化的桥梁
}

\author{
陈 芳 ${ }^{\mathrm{a}}$, 江训柱 ${ }^{\mathrm{a}, \mathrm{b}}$, 张䂞䂞 ${ }^{\mathrm{a}}$, 郎 奌 ${ }^{\mathrm{a}}$, 乔波涛 ${ }^{\mathrm{a},{ }^{*}}$ \\ ${ }^{\mathrm{a}}$ 中科院大连化学物理研究所催化基础国家重点实验室, 辽宁大连 116023 \\ ${ }^{b}$ 大连理工大学化学学院, 辽宁大连 116024
}

摘要: 催化在现代化学工业中占据着极为重要的地位. 催化剂是催化过程的核心. 均相催化剂由于具有均一、孤立的活性 位点, 往往具有高活性与高选择性; 但是分离困难限制了其实际应用. 多相催化剂由于金属原子利用效率低、活性组分不 均匀, 活性与选择性相对较低; 但其稳定易分离的特点使得目前大多数工业催化过程都是多相催化过程. 近年来, 单原子 催化逐渐成为催化领域新的研究热点与前沿, 受到相关研究人员的广泛关注. 作为一种多相催化剂, 单原子催化剂具有稳 定易分离的优势. 此外, 单原子催化剂具有类似均相催化剂的孤立活性位点, 可能具有高活性与高选择. 因此单原子催化 的概念一经提出, 便被认为有望成为架起多相催化与均相催化的桥梁; 但几年来并未从实验上得到证实. 2016 年开始, 逐 渐有单原子催化剂在经典均相催化反应过程中的应用报道, 为该观点提供了实验上的证据. 本综述概述了 2016 至 2017 年单原子催化剂在典型均相催化反应中的成功应用, 包括: 1) 氢甲酰化反应. 以烯烃和合成气为原料合成精细化学品醛类 化合物的氢甲酰化反应是目前化工生产中典型的均相催化反应之一. 2016 年, 张涛课题组和曾杰课题组先后报道了 $\mathrm{Rh} / \mathrm{ZnO}$ 和 $\mathrm{Rh} / \mathrm{CoO}$ 单原子催化剂在该反应中的成功应用. 催化剂都表现出优异的催化性能, 活性与经典均相 Wilkinson's 催化剂相当；2) 氢硅加成反应. 作为合成有机硅产品的重要反应之一, 工业上硅氢加成反应主要由 Pt 基均相催化剂催化. 2016 年 Beller 课题组首次报道了将 $\mathrm{Pt} / \mathrm{Al}_{2} \mathrm{O}_{3}$ 单原子催化剂用于烯烃硅氢加成反应中. 该催化剂除表现出良好的催化活性 和区域选择性外, 还具有较高的稳定性和底物普适性；3) $\mathrm{C}-\mathrm{H}$ 键选择性氧化. 烷烃部分氧化反应在学术研究和工业应用 方面都有重要意义. 刘文刚等将 M-N-C 单原子催化剂 (其中 $\mathrm{M}$ 为 $\mathrm{Fe}, \mathrm{Co}$ 等金属) 成功应用于 $\mathrm{C}-\mathrm{H}$ 键的活化反应中, 并对 催化剂的结构进行了深入剖析. 以上实例表明通过调控金属与载体组合、设计开发合适的单原子催化剂, 可以达到结合均 相催化高活性、高选择性与多相催化稳定易分离的目的, 为均相催化多相化提供了一条新途径, 也证明单原子催化可望成 为沟通均相催化与多相催化的桥梁.

关键词: 单原子催化; 均相反应多相化; 氢甲酰化反应; 氢硅加成反应; 碳氢键活化

收稿日期: 2017-12-23. 接受日期: 2018-02-02. 出版日期: 2018-05-05.

*通讯联系人. 电话: (0411)84379416; 传真: (0411)84685940; 电子信箱: bqiao@dicp.ac.cn

基金来源：国家自然科学基金 (21606222,21776270); 中国博士后基金面上资助 (2017M621170, 2016M601350).

本文的电子版全文由Elsevier出版社在ScienceDirect上出版(http://www.sciencedirect.com/science/journal/18722067). 